\title{
TERRITORIAL EXCLUSION
}

\author{
AN ARGUMENT AGAINST CLOSED BORDERS
}

\section{Daniel Weltman}

$\Omega^{t}$ UPPORTERS OF OPEN BORDERS sometimes argue that the state has no pro tanto right to restrict immigration, because such a right would also entail a right to exclude existing citizens for whatever reasons justify excluding immigrants. They argue that if a state can refuse to admit an immigrant into its territory and refuse to grant citizenship to an immigrant, it can also remove existing people from its territory and strip citizenship from a citizen or refuse to grant citizenship to newly born potential children. ${ }^{1}$ Thus one is excluded from a state if one ends up without a right to presence or citizenship in that state, and this exclusion can be visited upon current and incipient citizens just as much as it can be visited upon potential immigrants. Some argue that immigration restrictions would license the exclusion of anyone or almost anyone. ${ }^{2}$ Others argue that it would license the exclusion of people with certain political views

1 Theorists who endorse "closed borders," or in other words a pro tanto right for states to exclude immigrants, and who are thus targets of these arguments, include Blake ("Immigration, Jurisdiction, and Exclusion"), who argues that exclusion can be carried out in order to keep newcomers from unjustly imposing duties of redistributive justice on existing members; and Buechel ("A Presumptive Right to Exclude"), who offers a modified version of Blake's view. Theorists who argue that the state can exclude in order to preserve the character of a community (e.g., Walzer, Spheres of Justice; Miller, On Nationality and Strangers in Our Midst; and Pevnick, Immigration and the Constraints of Justice) say citizens have a right to claim the benefits of the institutions they have contributed to and the right to exclude others from obtaining those benefits. Other theorists endorse a strong right to freedom of association, which entails a freedom to refuse to associate with potential immigrants (Wellman, "Immigration and Freedom of Association"; Altman and Wellman, A Liberal Theory of International Justice), and a strong right to political self-determination, which entails rights to preserve the character of the community or otherwise determine its makeup (Moore, $A$ Political Theory of Territory, 189-97).

2 Cole, Philosophies of Exclusion, 51; Hidalgo, "Self-Determination, Immigration Restrictions, and the Problem of Compatriot Deportation"; Freiman, "The Marginal Cases Argument for Open Immigration”; Mendoza, "Enforcement Matters"; Akhtar, "Stripping Citizenship." 
or other cultural characteristics. ${ }^{3}$ Still others suggest that it would license the exclusion of newborn children. ${ }^{4}$

The thought is that exclusion in these ways is bad, and any theory that licenses exclusion is therefore bad, so we should reject these arguments that defend closed borders. We should not think states have a pro tanto right to exclude immigrants. To a large extent these arguments have gone unanswered, with the exception of replies from Thomas Carnes and Hrishikesh Joshi (discussed below). ${ }^{5}$ One potential way of responding is to draw a disanalogy between immigrants and existing citizens by arguing that there is a right to stay put, a right that allows existing citizens to remain but that also allows the state to exclude immigrants. ${ }^{6}$

In this article I present a new form of the exclusion argument against closed borders that escapes this kind of reply. I do this by describing a new kind of ex-

3 Kates and Pevnick, "Immigration, Jurisdiction, and History," 191-92.

4 Lægaard, “Territorial Rights, Political Association, and Immigration," 660-61; Brezger and Cassee, "Debate." Kieran Oberman offers a similar argument, which is that if it is ox to block immigration, it is oK to permanently deny citizenship to noncitizen residents. See Oberman, "Immigration, Citizenship, and Consent."

5 Carnes, "The Right to Exclude Immigrants Does Not Imply the Right to Exclude Newcomers by Birth"; and Joshi, "Is Liberalism Committed to Its Own Demise?" Altman and Wellman try to preempt the argument that their view allows for exclusion; see A Liberal Theory of International Justice, 184. I take Sahar Akhtar's reply to be compelling; see "Stripping Citizenship." Assuming Akhtar's reply fails, though, Altman and Wellman's response relies on the wrongness of kicking someone out of the territory they reside in, so it is not effective against my argument below. Louis Philippe Hodgson does not address immigration or exclusion directly, but he does argue that it can be wrong to impose duties of redistributive justice on people by having children, which could serve as a basis of an argument that licenses exclusion of newborns (although this would require modifications to Hodgson's specific argument, which is focused on the impact of newborns on other communities, not the community into which they are born); see "A Problem for Global Egalitarianism." Hodgson has a brief discussion of exclusion, although for a number of reasons it is not relevant here; see "A Problem for Global Egalitarianism," 198.

6 Carnes, "The Right to Exclude Immigrants Does Not Imply the Right to Exclude Newcomers by Birth," 30-31. Many endorse a right to stay put of some kind without committing one way or another to this particular debate over exclusion. See Nine, "A Lockean Theory of Territory"; Stilz, "Nations, States, and Territory"; Oberman, "Immigration, Global Poverty and the Right to Stay"; Miller, "Territorial Rights"; Stilz, "Occupancy Rights and the Wrong of Removal"; Moore, A Political Theory of Territory; Lefkowitz, "Autonomy, Residence, and Return," 540; Buckinx and Filindra, "The Case against Removal”; and Ottonelli, "The Right to Stay as a Control Right." As noted above, Altman and Wellman also endorse a right to stay put in response to the exclusion argument (A Liberal Theory of International Justice, 184). See also Stilz's defense of occupancy rights that entails the interesting combination of a limit on some exclusions, an endorsement of other exclusions, and open borders for cases in which immigration is innocuous ("Settlement, Expulsion, and Return" and Territorial Sovereignty). 
clusion that has not been discussed in depth, which I call "territorial exclusion."7 Territorial exclusion is the process according to which the group that wishes to exclude current citizens secedes from the territory in which those citizens reside. ${ }^{8}$ For instance, the forty-nine other states in the United States could secede from the worst state, Florida, effectively expelling Floridians from the country. I argue that defenders of closed borders cannot explain what is wrong with this sort of exclusion without vitiating the argument for closed borders. Thus, either states have a right to exclude via secession for whatever reasons they can exclude immigrants, or arguments in favor of a pro tanto right to exclude immigrants fail.

A virtue of this approach is that the territorial exclusion argument against closed borders does not rely on the idea that immigration restrictions are coercive. ${ }^{9}$ This is important because one might respond to existing exclusion arguments by making the following argument: states coerce people inside their borders but not people outside their borders, and thus states have a duty to grant citizenship to (and therefore not exclude) existing residents, but no duty to grant citizenship to outsiders. If we do not grant that immigration restrictions are coercive, then existing exclusion arguments are defeated by the coercion response. So, naturally, those who deploy exclusion arguments might claim that immigration restrictions are coercive. However, there are two issues with this reply on the part of existing exclusion arguments. The first is that this is controversial: many disagree that immigration restrictions are coercive. ${ }^{10}$ The second is that if we do grant that immigration restrictions are coercive, then it is not clear why we would need existing exclusion arguments. We could simply

7 Akhtar ends her discussion of exclusion with a brief paragraph on territorial exclusion in which she notes that endorsing the possibility of territorial exclusion is "a counterintuitive result" ("Stripping Citizenship," 433).

8 Adam Cox uses the phrase "territorial exclusion" to describe people kept out of a territory, as compared to people who are allowed into a territory but barred from certain benefits, like public assistance ("Three Mistakes in Open Borders Debates"). This is not the idea of "territorial exclusion" that I refer to here. Daniel Philpott uses the term "exclusion" to describe a situation in which "the citizens of one state do not want to allow an outside group of citizens to join," a problem he says is "insoluble" ("In Defense of Self-Determination," 381n55). One might worry that the similar situation in which most citizens of one state do not want to allow an inside group to continue to belong is similarly insoluble. I hope what I say below allays this concern.

9 The paradigmatic coercion-based open-borders argument is Arash Abizadeh's "Democratic Theory and Border Coercion." Other examples include those made by Huemer, "Is There a Right to Immigrate?"; and Freiman, "The Marginal Cases Argument for Open Immigration." See also Carens, The Ethics of Immigration, 257.

10 Altman and Wellman, A Liberal Theory of International Justice, 184; Miller, "Why Immigration Controls Are Not Coercive." 
rely on the coercion-based open borders argument. There is no way to draw a distinction between insiders and outsiders with respect to exclusion (according to exclusion arguments). But if this is true then coercion of insiders and outsiders is also equivalent, and thus coercion-based open borders arguments should be sufficient. Thus we might think that existing exclusion arguments are otiose: they succeed only if the coercion arguments for open borders also succeed (both kinds of arguments rely on the idea that immigration restrictions are coercive, because no distinction can be drawn between insiders and outsiders), and if those coercion arguments succeed, then we do not need these exclusion arguments. The territorial exclusion argument does not need the coercion argument for open borders at all. ${ }^{11}$ It will thus be able to convince those who reject coercion arguments. ${ }^{12}$

In section 1, I define key terms and briefly recap the existing exclusion arguments in favor of open borders and the objections to them. In section 2, I outline the territorial exclusion argument, which allows the opponent of closed borders to respond to these objections. In section 3 , I discuss objections to the territorial exclusion argument. In section 4 , I take stock and suggest that the best way to understand the territorial exclusion argument is not as one in favor of open borders but rather as one against closed borders and in favor of a more considered approach to which borders ought to exist in the first place.

Because my argument does not rely on coercion, it can serve as the basis of a similar cosmopolitan argument in favor of global duties of distributive justice. It can do this because some argue that coercion gives rise to duties of distributive justice and thus there are no substantial global duties of distributive justice absent a global scheme of coercion; see Nagel, "The Problem of Global Justice”; Blake, "Distributive Justice, State Coercion, and Autonomy” and "Agency, Coercion, and Global Justice"; and MacKay, "Coercion and Distributive Justice." What these arguments do not show, however, is that it is permissible not to globally coerce people who want to be coerced, which is clear if we imagine the state deciding to stop coercing some existing citizens as a way of getting out of its distributive-justice obligations to those existing citizens. If it would be wrong for the state to do this, then we might think it is equally wrong for a state to refuse to coerce willing outsiders on the grounds of not wanting to acquire duties of distribute justice to them. I discuss this possibility in Weltman, "The Shifting Boundary Problem” and "The Right to Join a State." See also Abizadeh, "Cooperation, Pervasive Impact, and Coercion."

It will not be much use for those who accept coercion arguments and who thus already accept open borders. But it is nice to have two arguments for the same conclusion that are not redundant in the way that coercion arguments and existing exclusion arguments are redundant. Moreover, as I note in section 4, I think open-borders arguments typically overreach, and this applies to coercion arguments too. I thank an anonymous reviewer for urging me to elaborate on this point. 


\section{KEY TERMS, THE EXCLUSION ARGUMENT FOR}

OPEN BORDERS, AND RESPONSES

By "open borders" I refer to the idea that states do not have a pro tanto right to prevent noncitizens from entering the state, residing in the state, and becoming citizens of the states. ${ }^{13}$ Advocates of "closed borders" typically only endorse broad pro tanto rights to prevent noncitizens from residing in the state for long periods of time and to prevent noncitizens from becoming citizens. That is, they often accept that states might lack a pro tanto right to prevent, say, tourists from visiting for short periods of time. ${ }^{14}$ "Immigration" refers to entering a state and residing there for a long period of time. Many people on both sides of the debate, following Michael Walzer, think that a right to immigration entails a right to citizenship, because a state cannot justly deny citizenship to long-term residents. ${ }^{15}$ Therefore, unless noted otherwise, a right to immigration entails not just a right to reside in a state long term but also a right to become a citizen. ${ }^{16}$ Supporters of open borders therefore think that everyone has at least a pro tanto right to immigrate anywhere they choose (and consequently become a citizen), and supporters of closed borders claim there is no such right. "Immigrants" refers to people who want to immigrate long term (and thus become citizens) rather than people merely traveling. A right to immigrate anywhere one chooses entails a correlative duty on the part of states not to violate this right, and the absence of a right to immigrate anywhere one chooses leaves room for a right on the part of states to prevent immigration. Thus a supporter of open borders thinks states have no pro tanto right to prevent someone from immigrating and supporters of closed borders think states do have a pro tanto right to prevent someone from

13 Fine, "Freedom of Association Is Not the Answer," 342-43. A pro tanto right is a right that can be overridden, i.e., a right that is not necessarily absolute. All things considered, a state may have a right to prevent someone from entering, perhaps to stop the spread of an epidemic. One could replace all talk of pro tanto rights with talk of conditional absolute rights (or even unconditional absolute rights) without changing the substance of my argument. On this topic generally, see Frederick, "Pro-Tanto Versus Absolute Rights." Rights arguments could be replaced altogether with arguments about moral considerations via the procedure outlined by Buchanan, Secession, 27-28. Altman and Wellman, A Liberal Theory of International Justice, 178. Walzer, Spheres of Justice, ch. 2; Miller, National Responsibility and Global Justice, 225; Altman and Wellman, A Liberal Theory of International Justice, 177-78; and Miller, Strangers in Our Midst, 63. For exceptions see Blake, "The Right to Exclude," 534; and Cox, “Three Mistakes in Open Borders Debates." and defends only the right to reside and not the right to citizenship also; see Sandelind, "Territorial Rights and Open Borders," 498-500. 
immigrating. An argument for closed borders must establish that there is no general pro tanto right to prevent immigration. There may be justifications for preventing immigration, but unless these apply to most potential immigrants, we must reject closed borders.

The exclusion argument against closed borders goes like this: any argument that explains why it is ox to refuse to admit immigrants will also work as an argument for excluding existing residents of the state, either by revoking their citizenship or by not granting them citizenship when they are born (or at any time subsequent to their birth). For instance, Michael Blake argues that states can restrict immigration because the relationship of co-citizenship entails duties, and people can permissibly avoid having these new duties thrust upon them by immigrants. ${ }^{17}$ But these new duties are also thrust upon people when newborn babies are given citizenship. ${ }^{18}$ So Blake's argument licenses the denial of citizenship to infants, and that is an unacceptable conclusion. Thus states have no pro tanto right to refuse immigrants. ${ }^{19}$

Or, similarly: Altman and Wellman argue that freedom of association, which allows people to associate together by forming states, also allows people to refuse to admit others into the association. ${ }^{20}$ But if people can refuse to admit new associates, they can also kick out existing associates. ${ }^{21}$ Freedom of association does not require me to associate with people I do not want to associate with, whether they are newcomers or existing associates. So Altman and Wellman's argument licenses the denationalization of existing citizens, and this is an unacceptable conclusion. Thus states have no pro tanto right to refuse immigrants.

17 Blake, "Immigration, Jurisdiction, and Exclusion" and "The Right to Exclude."

18 Lægaard, "Territorial Rights, Political Association, and Immigration," 660-61; and Brezger and Cassee, "Debate."

19 Blake himself compasses something very close to the infant-exclusion argument by asking whether his argument licenses "the right to slip birth control into our colleague's coffee to avoid" the "unwelcome burdens" entailed by newly born infants; see "Immigration, Jurisdiction, and Exclusion," 119. He suggests that the right to control one's body overrides someone else's right to secretly administer birth control. Of course, the right to control one's body does not require others to grant citizenship to one's newborn child, so his response here does not fully anticipate exclusion objections. As Blake points out, "nothing [he says] here demands, or permits, the idea that the right to avoid being obligated to others is morally absolute," which leaves room for exclusion arguments to suggest that the wrongs of exclusion outweigh the right to avoid acquiring new obligations to newborn co-citizens (119). See also Brezger and Cassee, "Debate," 374-75.

Wellman, "Immigration and Freedom of Association"; Altman and Wellman, A Liberal Theory of International Justice, ch. 7 .

21 Cole, Philosophies of Exclusion, 51; Gibney, "Should Citizenship Be Conditional?" 650; Brezger and Cassee, "Debate," 372; Akhtar, "Stripping Citizenship." 
To respond to exclusion arguments without giving up closed borders (and without endorsing exclusion of existing citizens or newborn babies), one must come up with some difference between people inside the state and people external to the state that explains why the former cannot be excluded while the latter can. ${ }^{22}$ One option is to say that people have a right to stay put. ${ }^{23}$ There are various ways one might defend this right, like a right to live in territory one is attached to, a right not to be coercively removed from one's home, a right not to be uprooted from one's neighbors, and so on. Any sort of argument like this that succeeds will rebut the exclusion argument, at least partially. One might still worry that infants could be excluded, and one might worry that citizenship can be stripped without deporting the noncitizens. ${ }^{24}$ But let us assume that a response based on the right to stay put is effective.

\section{THE TERRITORIAL EXCLUSION ARGUMENT}

Responses to the exclusion argument that depend on a right to stay put are powerless against the territorial exclusion argument. So, in effect, the territorial exclusion argument takes us back to where we were before the defender of closed borders points to the right to stay put: it takes us back to the point where, absent some way to distinguish between insiders and outsiders, defenses of closed borders also amount to defenses of exclusion. The territorial exclusion argument goes like this: if it is permissible for a state to use some criteria to refuse to grant citizenship to outsiders, then it is permissible for a state to use the same criteria to cut off some insiders from the state by seceding from the territory in which those insiders reside. But, exclusion via secession is no more acceptable than other forms of exclusion. Or, even if exclusion via secession is more acceptable than other forms of exclusion, it does not reach the threshold of acceptability

The language of "internal" and "external" is ambiguous with respect to immigrants who are already physically present in the state and who wish to avoid deportation, gain citizenship, or both. Does it amount to exclusion to deport them or deny them citizenship, or is it only exclusion if it is done to current citizens? I will ignore this complication and for the sake of simplicity treat immigrants as if they are all outside the borders of the state. This is not to imply that the question of open borders can be settled without also examining what this would entail for immigrants already within a state and others who would be influenced by the enforcement of closed borders. See Mendoza, "Enforcement Matters"; and Cole, Philosophies of Exclusion, 10-11. This is just to grant arguendo that there are no additional issues for the supporter of closed borders beyond exclusion arguments. Altman and Wellman, A Liberal Theory of International Justice, 184. izens. 
necessary to make it permissible to the degree that defenders of closed borders think immigration restrictions are permissible. So, to avoid commitment to the permissibility of exclusion, we should reject closed borders.

For instance, if it is ox for a state to close its borders to preserve the character of its community by refusing to admit immigrants who do not share the community's values, the state can also redraw its borders to exclude people living in a territory who do not share the community's values. Perhaps most of the state is one religion and most of the people belonging to another religion are concentrated in one area. The state can redraw its borders so that the territory inhabited by the religious minority is no longer part of the state, thereby withdrawing citizenship from the people in that territory. Such exclusion does not violate the right to stay put. Thus a right to closed borders, even granting a right to stay put, entails a right to territorially exclude. Or, say that it is or for a state to close its borders so that future newcomers do not impose unwanted duties of distributive justice on existing citizens. Similarly, imagine existing United States citizens do not want continued duties of distributive justice toward Floridians, who constantly require transfers of resources to offset the damage caused by hurricanes. So, the existing citizens all secede from Florida, excluding it from the United States. But exclusions of this sort are not ok. So, these criteria cannot serve as justifications for closed borders, because otherwise they would also license territorial exclusions. It is no help to point to a right to stay put, because the Floridians get to stay put.

If the territorial exclusion argument against closed borders does not work, it is because there is some difference between insiders and outsiders such that exclusion of outsiders is justified but exclusion of insiders is not. We have ruled out one possible difference, which is based on the right to stay put, because this difference will not block either kind of exclusion. Both kinds of exclusion are compatible with the right to stay put. So, to deny the territorial exclusion argument one must come up with a difference between insiders and outsiders that explains why the justification for excluding outsiders (by closing borders) is not also a justification for territorially excluding insiders.

In other words, in the face of the territorial exclusion argument, defenders of closed borders must come up with some answer other than the right to stay put. If, as David Miller argues, states can refuse immigrants because the right to self-determination allows a state to decide whether to incorporate new members who do not share the culture of the state and whom existing members do not trust, then the right to self-determination also allows a state to decide whether to exclude existing members who do not share the culture of a state and whom 
other existing members do not trust. ${ }^{25}$ If a state can exclude immigrants to keep its population under control, then it can exclude citizens to keep its population under control. ${ }^{26}$ For Altman and Wellman, almost any sort of desire no longer to associate with the excluded individuals would ground a right to exclude because nobody has to associate with anyone they do not want to associate with, and this includes existing associates (whom one can exclude) and not just prospective associates (to whom one can close one's borders). ${ }^{27}$ Blake argues that immigration limits can be justified by a right to refuse the imposition of unwanted distributive justice duties. ${ }^{28}$ His argument relies on "the right to avoid unwanted obligations, except when we have an existing obligation to acquire such new obligations." ${ }^{29}$ But this raises the question of why we only have a right to avoid new unwanted obligations rather than existing unwanted obligations. Is there any way to make this distinction that is not ad hoc? To do so, we must draw some distinction between insiders and outsiders. And so on for other defenses of limits on immigration. ${ }^{30}$

How compelling is the territorial exclusion argument? As an argument in favor of open borders the territorial exclusion argument is too fast. Some exclusions are objectionable, but others are not. Thus the argument cannot quite establish a requirement of open borders or even a strong presumption in favor of open borders. In fact, no exclusion argument can do either of these. In section 4 I defend the claim that exclusion arguments do not quite get us open borders: the argument above is too ambitious and does not quite succeed.

However, the exclusion argument does establish that we cannot accept closed borders. Recall that closed borders is the view that states have a pro tanto right to exclude basically all immigrants. Closed borders would license too

Miller, Strangers in Our Midst, 63-65.

Miller, Strangers in Our Midst, 65-66.

Altman and Wellman, A Liberal Theory of International Justice, 45-48. The only desires that would not ground a right to exclude (according to Altman and Wellman) are those that are objectionable for some other reason beyond the exclusion they license, namely those that disrespect existing citizens. So for instance if Florida was excluded because of a high concentration of Jews, this would not be acceptable — not because the Floridians have a right to stay but because Jews in the other forty-nine states could complain. So long as all the Jews were in Florida, though, this motive would be acceptable; see Altman and Wellman, A Liberal Theory of International Justice, 184-87. See section 3.2 for more discussion of this point.

Blake, "Immigration, Jurisdiction, and Exclusion."

Blake, "Immigration, Jurisdiction, and Exclusion," 119.

This is not to say that Miller, Blake, and others have no ways to draw a distinction. I countenance possible replies in section 3. The point is just that in the face of the territorial exclusion argument they need some reply. 
much exclusion, and exclusion is on its face objectionable. This is true of the territorial exclusion argument, at least, even if it is not true of the other exclusion arguments. ${ }^{31}$ There are two reasons the territorial exclusion argument defeats closed borders views, unless the closed border defender can come up with some distinction between insiders and outsiders that is not ad hoc.

\subsection{Widespread Permissible Exclusion Is Unintuitive}

The first reason is that the prospect of exclusion of any sort, including territorial exclusion, strikes many as objectionable on its face. Describing something as "exclusion" rather than "secession" rhetorically stacks the deck against it, and this is purposeful. The label highlights the intuitive pull of the territorial exclusion argument. As noted above, Akhtar suggests that "the view that states have authority to unilaterally decide their membership" would require us to say that "casting away unwanted members would ... be no different from secession," and this is "a counterintuitive result." 32 But if the exclusion argument works, then casting away unwanted members is no different from secession. Indeed, for theorists like Altman and Wellman, for whom exclusion is licensed by the right to self-determination, exclusion is secession. ${ }^{33}$ They defend "an unusually permissive stance on state-breaking" according to which a group can secede for basically any reason, so long as it and the state it leaves behind are able to carry out the requisite functions of a state. ${ }^{34}$ This permissive approach to secession allows for exclusion just like it allows for any other secession one might imagine.

For theorists who do not endorse permissive views on secession more generally, they are typically at pains to show that their theory does not entail a right to exclude, and so they will not be happy if their theory entails a right to territorially exclude. (This is doubly the case because many may not want to endorse a permissive right to secede at all, but according to the territorial exclusion argument, any limitation on immigrants generates a right to secede, and thus perhaps permits more secession than one would like to otherwise permit.) This is why

Beran, The Consent Theory of Political Obligation; and Steiner, "May Lockean Doughnuts Have Holes?” If one can secede for almost any reason, one can engage in territorial exclusion for almost any reason, because territorial exclusion is merely secession described differently. See also section 3.2.

34 Altman and Wellman, A Liberal Theory of International Justice, 43. 
Carnes attempts to show that closed borders arguments do not license exclusion of insiders. ${ }^{35}$

Territorial exclusion strikes some people as so obviously illegitimate that it is a mistake to even countenance its possibility. As Hilliard Aronovitch puts it, "while we may grant that a seceding unit may somehow sensibly claim an equivalent reason [to no-fault divorce] for leaving a country, surely there is no reciprocal right for the rest of the country to turn around against some part and by a majority decision simply opt to end its relationship to that part." ${ }^{36}$ Similarly, Jason Blahuta suggests that "the ability to leave is not held by both parties when it comes to secession. Were both parties able to remove themselves from their relationship with the other, it follows that a subunit confined to a specific territory and recognized as a people could be expelled from the nation against their will and without provocation (although the most plausible reason would be an economic one). Such an occurrence between peoples seems very counterintuitive. ${ }^{37}$ Aronovitch and Blahuta perhaps go too far if they are suggesting that these possibilities are so outré as to be clearly unjustifiable, and in section 4 I will defend the idea that territorial exclusion could in principle be justified in some cases, but one might think that they are both right to claim that territorial exclusion is prima facie worrying such that we should reject closed borders, since closed borders license widespread territorial exclusion.

It is true that, far from being a conclusion to avoid, the possibility of territorial exclusion is straightforwardly endorsed by some theorists. The clearest example is Altman and Wellman, who have a quite permissive theory of secession and who thus would have no problem with territorial exclusion. ${ }^{38}$ So, one might object to Akhtar, Aronovitch, Blahuta, and others for whom the prospect of exclusion is unintuitive by saying that their intuitions have gone askew. There are two things to say in response to this objection. First, Altman and Wellman accept exclusion because they are so permissive with respect to secession, but permissiveness with respect to secession strikes many people as equally unintuitive. So, although one might commend Altman and Wellman for consistency, they pay for it with plausibility. Ruling out all unilateral secession is perhaps too restrictive, but we do not need to be as permissive as Altman and Wellman are. In the fight over intuitions, so to speak, few are going to line up on the side that

Carnes, "The Right to Exclude Immigrants Does Not Imply the Right to Exclude Newcomers by Birth.”

36 Aronovitch, "Why Secession Is Unlike Divorce," 30.

Altman and Wellman, A Liberal Theory of International Justice, ch. 3. 
permits widespread secession. And if they do not line up on that side, they cannot line up against the territorial exclusion argument.

Second, it could be that, in the terms of bare permissibility, we should license exclusion, but this is no argument in favor of exclusion in any particular case, which means the presumption should still be in favor of no exclusion and in favor of open borders, not because this is the default but because we think this is the result we will arrive at each time. That is, just like Altman and Wellman are happy to grant that the rights to secede and to block immigrants are pro tanto rights (albeit very strong pro tanto rights that will typically win out unless there are much stronger considerations in the offing), we can grant the same and say that in almost every case there will be considerations that trump these pro tanto rights. Technically this response does not save the territorial exclusion argument because it grants that exclusion is permissible and that closed borders are permissible. It just pushes the question back to the balancing act: on the one side we have the pro tanto right to exclude existing citizens and immigrants and on the other we have whatever other concerns exist. This sort of response will be discussed in section 4, where I suggest that ultimately our approach to the subject should not be an assumption of closed borders or open borders but rather an approach that takes into consideration the balancing that needs to be done.

Either way, the territorial exclusion argument at least brings into sharp focus the fact that one must hold a very permissive theory of secession (that permits exclusion) in order to defend closed borders. In sum, the first reason to endorse the territorial exclusion argument is that exclusion of any sort is intuitively objectionable, and thus we should reject closed borders views because they permit lots of territorial exclusion (unless they can draw a distinction between insiders and outsiders; see section 3.1). I think accepting such a permissive theory of secession is unattractive enough that the territorial exclusion argument defeats closed borders views.

\subsection{The Moral Arbitrariness of Borders}

Second, the territorial exclusion argument defeats the closed borders position because it is another way of articulating the challenge of the moral arbitrariness of borders. The moral arbitrariness of borders refers to the idea that where one is born, and thus whether one is an immigrant or a citizen with respect to any given state, is merely up to chance, and thus this at least calls into question the idea that one's life circumstances should be drastically impacted by one's citizenship. ${ }^{39}$ There is controversy over whether and how borders are morally arbitrary

39 For an extensive discussion of this point with respect to Blake's attack on it, and a defense of the anti-exclusion view, see Arrildt, "State Borders as Defining Lines of Justice," 13-16. For 
and over what conclusions we should draw from their arbitrariness. We do not need to resolve these questions here. We just need to realize that the territorial exclusion argument brings to light one facet of the moral arbitrariness claim: it shows the need for drawing some distinction between insiders and outsiders if one wishes to avoid endorsing exclusion. This is because, as the territorial exclusion argument points out, exclusion can be justified by the same principles that justify closing borders. There is no difference between refusing to let someone in and refusing to let someone stay in unless we introduce some further principle to explain the difference. That is a point that all exclusion arguments raise, but the non-territorial exclusion arguments face the reply from the right to stay put. The right to stay put is a distinction between insiders and outsiders. Because the territorial exclusion argument avoids the right to stay put reply, it brings us back to the status quo. The status quo is that there seems to be no distinction between insiders and outsiders that would justify closed borders but not territorial exclusion. ${ }^{40}$

This can be seen by examining Blake's discussion of something close to territorial exclusion. Blake imagines a state in the United States, or a city in the United States, closing its borders to other United States citizens, which is effectively a form of territorial exclusion, albeit less drastic than full secession. ${ }^{41} \mathrm{He}$ realizes that if states, cities, and other subunits had rights to exclude, this would be unintuitively strong. He responds by suggesting that such a right to exclude "is anathema to the project of creating a single political community"- there is a "project of shared self-rule entered into at the federal level" that binds existing political entities together and prevents any entity from doing anything that would damage or destroy the community. ${ }^{42}$ If the argument is merely that exclusion of insiders is not oK because they are insiders, this is ad hoc and it begs the question. If the argument is that there is something special about the existing relationships, then we have a potential reply to the territorial exclusion argument. So it is to this that we now turn.

more on the moral arbitrariness of borders generally, see Nine, "The Moral Arbitrariness of State Borders" and Global Justice and Territory, ch. 5; Fine, "Freedom of Association Is Not the Answer," 338; Armstrong, "National Self-Determination, Global Equality and Moral Arbitrariness"; and Stilz, Territorial Sovereignty, 17.

This is not to say that there is no hope for anyone who attempts to draw such a distinction. In section $3.1 \mathrm{I}$ cover various attempts to draw the distinction. The point is that, without such a distinction, closed borders entail the acceptability of territorial exclusion.

Blake, "Immigration, Jurisdiction, and Exclusion," 122.

Blake, "Immigration, Jurisdiction, and Exclusion," 123. 


\section{OBJECTIONS}

\subsection{Existing Relationships}

One might object that the territorial exclusion argument fails because it does not take into account one main difference between existing citizens and potential immigrants: there is an established relationship between existing citizens in a state that it would be wrong to eliminate, and this relationship does not exist between citizens and potential immigrants. ${ }^{43}$ The relationship could be thought of as a national project or a shared history or a pattern of cooperation or something along these lines. ${ }^{44}$ So, we can defend closed borders without also having to defend territorial exclusion, because territorial exclusion disrupts existing relationships whereas closed borders do not. This defense would help keep theorists like Blake from falling prey to the exclusion argument because Blake could draw a distinction between existing relationships (that cannot be severed) and potential future relationships (that we could keep from coming into existence).$^{45}$

The thought is that there is something about existing relationships between co-nationals that undergirds associative duties between the co-nationals and that is valuable. And so, according to this objection, there would be something wrong with losing the valuable relationship, and this is a wrong that does not arise merely from closing borders. Hence, we have an argument against territorial exclusion (that damages the relationship) but not against closed borders (that leave relationships intact). The relationship itself might be valuable because there is something good about "engagement in a joint political venture" with one's co-citizens. ${ }^{46}$ Or maybe the fact that society is "a cooperative venture for mutual advantage" makes the relationship valuable. ${ }^{47}$ Or the relationship inspires trust and loyalty that make possible the implementation of a welfare

This argument does not work against newborn exclusion arguments unless it ties the relationship to the parents of the infant. It also does not work against immigrants who already live in the country they aim to join and who have thus established relationships, and it does not work against immigrants who have lived near the border for a long time and formed relationships with citizens. It also may not work with respect to hermits and other citizens who have not formed ongoing relationships with their co-citizens; see Lenard, "Democratic Citizenship and Denationalization," 4. I put all these issues aside because they are not relevant to the territorial exclusion argument. Stilz, "Decolonization and Self-Determination."

Blake, "Immigration, Jurisdiction, and Exclusion." As noted above, it is also close to an actual argument Blake makes about federalism, so it is likely he would take this route to combat the territorial exclusion argument. 
state. ${ }^{48}$ Maybe the relationship came about as a result of a promise and it would be wrong to break the promise. ${ }^{49}$ There are two main responses to this objection.

\subsubsection{Proving Too Much}

The first response is that we want to be careful that we do not prove too much. This objection, unless it is qualified somehow, rules out pretty much all unilateral secession. (The one exception is that it may not rule out secession by badly mistreated groups, because in this case there is likely no valuable relationship that deserves protection..$^{50}$ ) When Blake suggests that "the project of creating a single political community" would be damaged by territorial exclusion, he is correct, but unless he wants to claim that all political communities are eternally inviolable, this point is not enough on its own. ${ }^{51}$ The principle that existing relationships are special could even rule out emigration on the part of citizens whom the state does not wish to let go. ${ }^{52}$ Perhaps it even rules out unilateral divorce, if relationships between people are valuable like relationships between the state and its citizens are valuable.

Since it seems reasonable to say that sometimes unilateral secession is permissible and sometimes it is not, and perhaps even sometimes emigration restrictions are permissible (like to prevent brain drain) but usually they are not, and of course sometimes unilateral divorces are permissible, this points us toward

48 Miller, On Nationality, 92-94. One account of the value of the relationship that will not work is that the relationship in its current form is affirmed by (or desired by) every member. This is false in cases of exclusion, where some of the members are trying to sever the relationship. If being valued by all the existing members were what makes a relationship valuable, then in cases of potential exclusion there would be no valuable relationship and thus nothing to block exclusion. Thus theorists like Altman and Wellman, for whom the collective value of self-determination depends on the fact that the people want to constitute a "self," cannot avail themselves of this objection against the exclusion argument; see A Liberal Theory of International Justice, 44-48. In exclusion cases, the people no longer wish to constitute a single "self." For discussion, see Weltman, "Who Is the Self in Self-Determination?"

49 Someone who advances this objection is pushed toward a consent theory of political obligation as in Beran, The Consent Theory of Political Obligation. Such theories face other issues. See Weltman, "Plebiscitary Theories."

The right to secede for mistreated groups is known as the "remedial" theory of secession and is defended chiefly by Buchanan, Secession. As Catala notes, there are reasons to worry that remedial theories of secession in fact collapse into theories that rely on nationalist projects or other sorts of relationships, so remedial theories may not even be an exception ("Remedial Theories of Secession and Territorial Justification"). Even if Catala is wrong, remedial theories probably collapse into some other theory when it comes specifically to exclusion, for reasons noted by Dietrich ("Secession of the Rich").

Blake, "Immigration, Jurisdiction, and Exclusion," 123.

52

Cole, Philosophies of Exclusion, 49. 
something of a reconciliation. ${ }^{53}$ What we need is a theory according to which we can adjudicate when it is and when it is not ox to unilaterally sever existing relationships. It is too harsh to say we can never break them off, so this will not work as a way of ruling out the territorial exclusion argument against closed borders. But it seems equally harsh to say that we can always break them off, so this does suggest that, sometimes, the territorial exclusion argument will not deliver open borders.

In section 4, I discuss theories of when it is and is not oK to break off ongoing relationships. For now, the relevant point to keep in mind is that this response does not always work against the territorial exclusion argument. It does not establish a general pro tanto right for states to close their borders. It could only do this if it established a universal requirement that nobody ever break off any existing valuable relationships, which is implausibly strong. ${ }^{54}$

\subsubsection{Taking Stock}

Second, it is worth taking a step back and remembering that, although the debate is about whether some given argument for closed borders also serves as an argument for territorial exclusion, the broader context is whether there are good arguments for or against closed borders more generally. If the best argument we can come up with for closed borders is one that relies on the fact that borders have been closed in the past and that, because of this, certain relationships have been established, we are begging the question. Potential immigrants would like to enter into precisely the sorts of relationships at issue in this objection, and pointing out that they have yet to do so and using this to establish that they have no right to do so is a little perverse. ${ }^{55}$ As Johann Frick notes, this procedure (which he labels "double-jeopardy") is so perverse as to sink all limitations on immigration based on associative duties. ${ }^{56}$

So, even granting for the moment that this objection succeeds in showing that there is an argument for closed borders that does not license territorial exclusion, it may be that this argument for closed borders merely consists of reasserting that borders have been closed so far, which is hardly an argument. As Cole puts it, "the question here is whether non-citizens have a moral right of immigration into a state, in a similar way that citizens do, and this cannot be settled by appeal to the fact that citizens are granted this right by the state

Oberman, "Can Brain Drain Justify Immigration Restrictions?"

54 I thank Dan Guillery for discussion of this point.

55 Carens, The Ethics of Immigration, 282.

56 Frick, "National Partiality, Immigration, and the Problem of Double-Jeopardy." 
while non-citizens are not." ${ }^{57}$ Existing relationships exist between citizens only because citizens have already been granted the right to form and maintain these relationships. "We've always done it this way" is, upon reflection, not always a good moral justification for a practice. ${ }^{58}$

\subsubsection{Pevnick on Existing Relationships}

A more focused defense of the existing relationships objection can be found in Pevnick, who argues that groups of people contribute to the creation and maintenance of the state and in virtue of this they get to decide who will make decisions in the future, which gives them a right to exclude immigrants. ${ }^{59} \mathrm{I}$ have six things to say in response.

First, giving everyone a say in decisions about what future citizens look like is not the same as making sure everyone gets their way, and it is not the same as including all present or future people in that future citizenry. So for instance Floridians might desire that the Us let in a million immigrants, but they get outvoted by the rest of the Us. Similarly, Floridians might desire that the us let in the next generation of Floridians, or retain the current generation of Floridians, but they get outvoted and excluded. These results are all on a par. Anything justify-

This argument shares some features in common with the "distributive objection" attacked by Seth Lazar and first raised by Scheffler; see Lazar, "Debate," 91; and Scheffler, Boundaries and Allegiances. Lazar suggests that the distributive objection is flawed because it assumes a "pre-existing inequality" between universal moral duties (which would be the duties owed to immigrants) and duties based on special relationships, whereas in fact "associative duties and general duties are co-originary" ("Debate," 94). (For more on the distributive objection, see Seglow, "Associative Duties and Global Justice.") While this argument may have merit against the quick claim that any past association is never a moral justification for future partiality, it does not defeat my claim here that some past associations may fail to justify some partialities, in this case the partiality necessary to defend closed borders. For a similar argument, see Frick, "National Partiality, Immigration, and the Problem of Double-Jeopardy." Hidalgo provides a similar argument against existing relationships grounding a right to close borders in "Associative Duties and Immigration." His argument contests Lazar's rather moderate defense of some associative duties; see Lazar, "Debate" and "A Liberal Defence of (Some) Duties to Compatriots." I am not even sure Lazar thinks that associative duties can ground a right to close borders, so his arguments may be no help for closed borders advocates. For further discussion on the topic of associative duties versus duties to outsiders, see Scheffler, Boundaries and Allegiances; and Arneson, "Extreme Cosmopolitanisms Defended." For more arguments against the notion that special obligations ground a right to close borders, see Abizadeh, “The Special-Obligations Challenge to More Open Borders." I thank an anonymous reviewer for raising the Lazar point, about which there is more to say than can fit in this footnote. 
ing the immigrant exclusion result will also justify the Floridian exclusion result, despite the fact that Floridians get to vote in all of the decisions.

Second, this works at the individual level too. It still lets us exclude newborns. Pevnick has to wheel in other considerations to explain what is wrong with newborn exclusion. ${ }^{60}$ Perhaps it is fine if our response to exclusion arguments is piecemeal like this: one response to territorial exclusion, another to newborn exclusion. But if we can find a holistic theory that answers all exclusion arguments in one go, either by accepting them and endorsing open borders or by giving a more nuanced reply, I think we should at least be pushed in that direction.

Third, it is one thing to say that a state has to include certain people who have contributed. It is another to say it has to include a certain territory. The Us might vote to exclude Florida but grandfather in existing citizens, but only for a limited time. If they do not move from Florida and keep contributing to the us (as opposed to contributing to Florida, which no longer counts), then by Pevnick's own lights they will lose the right to be included. Many of them of course will not want to move, so they will end up excluded. Also, all new people born in Florida or immigrating to Florida will be excluded, since they will not have been grandfathered in. This is particularly a problem because this kind of "slow denationalization" is a mirror of the process that most defenders of closed borders endorse for immigrants. They suggest that immigrants should be allowed into a country for a limited period of time, and that deportation is only justified in order to keep them from staying too long and acquiring citizenship, which a state owes to every long-term resident. If it is oK to force an immigrant to move after a period of time to keep from having to give them citizenship, why is it not ox to force a citizen to move after a period of time to avoid losing citizenship? The two situations are on a par. ${ }^{61}$

Fourth, maybe the Floridians have not contributed. Maybe from day one they have been battered by hurricanes and thus they have been a net drain on the society. In fact, this is why the Us wants to exclude Florida. ${ }^{62}$ This does not make it any more acceptable to exclude Florida than if it had contributed a lot. In fact, although one sort of wrong consists of draining resources from people, another sort of wrong consists of preventing them from contributing. Exploitation is one of the faces of oppression described by Iris Marion Young, but so is

60 Pevnick, Immigration and the Constraints of Justice, 64-66.

61 This reply works against others who endorse a right to close borders, like Blake.

62 Compare Hidalgo's case of Leticia in "Self-Determination, Immigration Restrictions, and the Problem of Compatriot Deportation," 265. This is a hypothetical example-I am not taking a position one way or the other on whether Florida has been a net drain on the United States. 
"marginalization," according to which people are rendered "marginals," or "people the system of labor cannot or will not use."63 So, Pevnick's approach could have the perverse result that people excluded from contributing to society via marginalization are the most liable to being excluded from that society entirely.

Fifth, if there is any case where exclusion maybe does seem justifiable, it is precisely the case where people have contributed a lot. So for instance if the us wanted to exclude the richest state, which continually pays taxes to other states and supports them (perhaps because that rich state has all the rich capitalists who keep using their money to influence politics, and the us wants to become a socialist utopia) it seems like this is the case where exclusion can most easily be justified. Those people will be quite well-off on their own, with their yachts and whatnot. They have nothing to worry about. Any worries about excluding the marginalized seem inapposite since these people have not been marginalized. So despite being their being intimately tied up with the existing institutions of the us, kicking out the rich does not seem anywhere near as objectionable as kicking out poor benighted Florida.

Sixth, it cannot be the case that questions of inclusion turn solely on this question. Pevnick himself notes that this is just one consideration to add into the calculation. ${ }^{64}$ Once we admit this, though, there is the question of how much weight to give it. I suggest that we give this consideration very little weight. That people have contributed to the creation and maintenance of a particular state is in many cases at best an accident of history and at worst a result of systemic oppression and exploitation. If we restrict ourselves only to extremely just states, there are still reasons for thinking that the state's ability to control what it looks like in the future should be outweighed by other sorts of considerations, like any considerations that would tell in favor of allowing an immigrant to choose where to live. These include global justice considerations, the right to freedom of movement, and worries about whether the right to self-determination (which undergirds the state's right to determine its future makeup) is strong enough to play the role Pevnick says it should. As Fine points out, we already accept that self-determination is not strong enough to allow the state to prevent existing residents from having children. ${ }^{65}$ If Pevnick's concerns do not answer the infant exclusion argument, why do they answer the territorial exclusion argument? ${ }^{66}$

63 Young, Justice and the Politics of Difference, 53.

64 Pevnick, Immigration and the Constraints of Justice, 40, 65-66.

65 Fine, “The Ethics of Immigration," 263-64.

66 I present more arguments for thinking that the right to self-determination is not strong enough to establish Pevnick's conclusion in Weltman, "Against Innovative Accounts of Self-Determination." 
There are more objections one might make to Pevnick's picture. ${ }^{67}$ There is Sarah Fine's point that sometimes outsiders have contributed to a state and thus they should have a right to immigrate. There is Michael Blake's objection to Pevnick's Lockean account of property rights. There is Javier Hidalgo's suggestion that Pevnick does not escape the original non-territorial exclusion argument. Brezger and Cassee suggest the same thing. ${ }^{68}$ So, even if my six replies do not work, one need not accept Pevnick's account, and if we can reject Pevnick, the territorial exclusion argument remains undefeated.

\subsection{The Motive Does All the Work}

Another possible objection is that an objectionable exclusion is objectionable due to bad motives on the part of the excluders, and it is the motives that explain the wrongness of the exclusion. Wanting to kick out Florida because it is a drain on resources is wrong not because exclusion is wrong but because this is selfish. It would be fine to exclude for other reasons. So, there is nothing wrong with exclusion in principle, so long as the motives are pure. ${ }^{69}$

I can basically accept this objection, because in section 4 I will agree that the territorial exclusion argument does not always get us open borders. But this does not get use closed borders, either. It just gets us the claim that good motives can justify closed borders. It does not yet tell us what good motives are. For all that has been said here, there are no good motives for closed borders. Indeed, we should be skeptical that there are any good motives for the idea that the state has a pro tanto right to exclude anyone. That is a very broad right. It would be akin to saying the state has a pro tanto right to territorially exclude any existing citizens. It is hard to think of good motives for that. However, adjudicating the balance of reasons for and against exclusion comes later. For now the point is just that we cannot establish the truth of the closed borders view merely by admitting that it is in principle acceptable to practice territorial exclusion. The territorial exclusion argument shows that, to establish closed borders, we must cough up some further justification.

67 See also Jeremy Waldron's examination of a theory similar to Pevnick's, albeit not Pevnick's theory itself, in "Exclusion."

68 Fine, "The Ethics of Immigration," 264; Blake, “The Right to Exclude," 531; Hidalgo, "Self-Determination, Immigration Restrictions, and the Problem of Compatriot Deportation," 268-69; Brezger and Cassee, "Debate," 375-76. Brezger and Cassee's criticism focuses on Pevnick's claim that existing citizens must consent to the arrival of new citizens. Shelley Wilcox offers a similar criticism of Pevnick's claim that does not focus on exclusion particularly but on whether the consent condition can be justified; see review of Immigration and the Constraints of Justice, 621-22.

69 I thank Tom Parr for discussion of this point. 
A second, less conciliatory response is to note that, at least for some closed borders advocates, one's motive has to be quite bad in order to defeat the presumption in favor of a right to closed borders. Walzer, for instance, defends the idea that Australia could close its borders for the sake of creating a racist white ethnostate so long as it practices preemptive territorial exclusion by giving up its excess land to immigrants from Southeast Asia who need a place to live. ${ }^{70}$ As he puts it, "White Australia could survive only as Little Australia." 71 This is meant to be a limit on the rights of the white Australians, who do not get to keep all their land. But it is also a defense of the right of the white Australians to limit immigration for objectionable reasons. Obviously Walzer and other defenders of closed borders do not need to be sanguine about racist border controls, and many defenders of closed borders do not go quite as far as Walzer. ${ }^{72}$ Altman and Wellman do say that "legitimate states are entitled to reject all potential immigrants, even those desperately seeking asylum from tyrannical governments," but they think some reasons for rejection are not legitimate because these reasons disrespect current citizens. ${ }^{73}$ If the only citizens who are disrespected are those being excluded (like if Floridians are disrespected, but only because all of Florida is being excluded), then this is no defense against the territorial exclusion argument. Defenders of closed borders can even believe that it is typically a good thing for states not to exercise their right to exclude. But if the right to exclude immigrants has any force at all, it needs to be a relatively robust right. As Jeremy Waldron points out, there is little use in speaking of rights if they do not entail "a moral right to do something that is, from the moral point of view, wrong. ${ }^{74}$ So if closed borders positions in fact establish a right to exclude immigrants, it is probably most charitable to read them as establishing a right to exclude immigrants for at least some objectionable motives. If this is true, then territorial exclusion for objectionable motives would also end up justified, and this is a result we want to avoid.

\subsection{Right to Stay Put}

In section 1, I granted for the sake of the argument that the right to stay put is

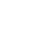 think that those who do not go as far as Walzer are not justified - that is, perhaps one must be as radical as Walzer if one defends closed borders. Defense of this point exceeds the scope of this article.
Altman and Wellman, A Liberal Theory of International Justice, 186-87. There are reasons to

Walzer, Spheres of Justice, 46-48.

Walzer, Spheres of Justice, 47. Altman and Wellman, A Liberal Theory of International Justice, 188.

Waldron, “A Right to Do Wrong," 21. 
effective against other exclusion arguments. The territorial exclusion argument, I claimed, avoids the right to stay put objection because people who are territorially excluded get to stay put. But, one might object, the right to stay put is not just a literal right to sit around, as it were, but rather a right to a variety of things, including a continuing relationship with one's co-citizens, such that territorial exclusion would violate this right to stay put. ${ }^{75}$ This is one way to read Carnes's objection to earlier newborn exclusion arguments: he suggests that newborn exclusion is wrong not because of the harm it does to the newborns but because "one's state coercively frustrating" a morally important interest "is presumptively wrong insofar as it constitutes an objectionable harm," and so "a state's right to exclude nonmembers is constrained when that right conflicts with its members' more central right to procreate and raise families." ${ }^{76}$ One might think that other rights are central to one's morally important interests, and territorial exclusion would coercively frustrate these rights in ways that excluding immigrants would not.

If this argument works, it would have to be the case that territorial exclusion coercively frustrates morally important interests of those who are excluded. ${ }^{77}$ What interests might these be? Notice first that if such interests exist then it is not clear that unilateral secession would ever be justified, as noted in section 3.1.1. This seems too strong.

Second, for this argument to work, the interests cannot be interests shared with potential immigrants, which cuts down on many of the good candidates, like an interest in living in the state of one's choice or an interest in availing oneself of opportunities attached to living in a state of one's choice or an interest in associating with people one wishes to associate with.

Third, as noted in section 3.1.2, we want to be careful not to pick interests that are unique to citizens merely because the state does not currently permit immigrants. That is, if the morally relevant difference between citizens and immigrants is that the citizens are already citizens, this argument is viciously circular: citizens cannot be excluded because they have an interest in remaining citizens, an interest that exists because they are citizens, whereas immigrants can be excluded because they have no such interest, but they lack this interest only because they have been excluded. If that exclusion was unjustified then it should

I owe this objection to an anonymous reviewer.

76 Carnes, “The Right to Exclude Immigrants Does Not Imply the Right to Exclude Newcomers by Birth,” 38.

77 For a number of reasons I do not think coercive frustration, as opposed to frustration, is morally relevant here. Thus I think a charitable reconstruction of Carnes ought to drop coercion from the picture. 
not matter that they lack the interest. If I only allow the men in my class to submit extra-credit assignments, and then I propose to grade only those submitted by freshmen who are men and not those submitted by sophomore men, it is fair to say the sophomore men have an interest in their assignments being graded too, and it is unjust for me to frustrate this interest. I cannot grade any assignments submitted by the women in my class because I have not allowed them to submit the assignments. But the women are being treated just as unfairly as the sophomore men when their assignments are not graded. It is no use for me to say that they do not have an interest in having their assignments graded because they never submitted any. The only reason they did not submit assignments is that I did not let them submit assignments. ${ }^{78}$ So, just pointing to an interest that existing citizens have will not do the work. We must also justify the fact that only existing citizens have this interest. Otherwise we beg the question in favor of closed borders views.

\subsection{Carnes and Joshi on Exclusion}

As noted above, the main reply to exclusion arguments is that provided by Carnes. His focus is entirely on infant exclusion arguments, and there are reasons to think his replies do not succeed even against those. Carnes argues that it would be wrong to exclude newborn infants because "state exclusion of newcomers by birth would constitute a genuine harm to those newcomers' parents." ${ }^{79}$ This implausibly implies that the state does nothing wrong when it excludes newborn orphans. It may also allow the state to deny and later deport children born to noncitizens, and thus denies the principle of jus soli that many take to be an important aspect of justice. ${ }^{80}$ Moreover, Carnes sums up his argument like this: "if one's interest in raising a family is central to one's conception of a good life, and pursuing that interest is not disproportionately burdensome to others, then one's state coercively frustrating that interest is presumptively wrong insofar as it constitutes an objectionable harm." ${ }^{81}$ But the state does not always coercively frustrate this interest by excluding newborn infants. An infant born to parents

78 See also Frick's Princeton example, which makes a similar point, in "National Partiality, Immigration, and the Problem of Double-Jeopardy."

Carnes, "The Right to Exclude Immigrants Does Not Imply the Right to Exclude Newcomers by Birth," 38 .

80 Cf. Carnes, "The Right to Exclude Immigrants Does Not Imply the Right to Exclude Newcomers by Birth," 29n3; and Ferracioli, "Citizenship for Children." It might also allow the state to deny citizenship to infants who are born to people liable to denationalization. For an overview of denationalization, see Ferracioli, "Citizenship Allocation and Withdrawal."

81 Carnes, "The Right to Exclude Immigrants Does Not Imply the Right to Exclude Newcomers by Birth," 38 . 
who are citizens of another country (or multiple other countries) with jus sanguinis laws that grant citizenship to that infant could in many cases be excluded without frustrating the interest the parents have in raising a family. This is potentially true even if the infant does not already qualify for other citizenships via jus sanguinis or anything else, so long as the parents could find some acceptable way to raise the infant without that infant getting citizenship in its country of birth. For instance, if the parents are rich and well-connected, they may not find it too difficult to raise their infant in another country and arrange for the infant to acquire citizenship in that other country after some time.

Assuming, though, that Carnes can respond to these objections, the most apposite reply to his argument is that, because it is aimed only at newborn exclusion arguments, it has no bite against the territorial exclusion argument. ${ }^{82}$ This is one virtue of the territorial exclusion argument: it escapes objections that potentially succeed against other exclusion arguments. Thus even if one finds the present argument less powerful (because states will be more reluctant to lose territory via exclusion than they would be to exclude people via other means) this downside is compensated for by one upside: the argument is less vulnerable to objections.

Besides Carnes, the main reply to exclusion arguments consists of Hrishikesh Joshi's brief discussion of the topic. Joshi realizes that immigration restrictions might be wielded to justify excluding existing citizens on the same basis, and responds that it is less of an imposition on freedom to prevent immigration than it is to deport an existing citizen, and that even if in principle a state would be justified in excluding citizens for the same reasons it excludes immigrants, in practice this would be liable to abuse and thus should be forbidden. ${ }^{83}$ It is not clear how compelling either response is, but we can grant for the sake of the argument that they work against existing exclusion arguments. ${ }^{84}$ With respect to the territorial exclusion argument, these responses are less clearly compelling.

Start with Joshi's first reply. Is the violation of one's freedoms when one is seceded from against one's will much more drastic than the violation of one's freedoms when one is prevented from immigrating into a state? This is unlikely, for two reasons. First, being deported from one's state entails being kicked out of

82 Two further issues one might have with Carnes are that his approach does not capture the intuition that the infants (rather than just the parents) are harmed when they are denied citizenship, and that Carnes must bite the bullet and say there is nothing wrong with denying citizenship to an infant if the parents consent.

83 Joshi, "Is Liberalism Committed to Its Own Demise?” 264-65.

84 I argue that Joshi's claims are not compelling in Weltman, "Illiberal Immigrants and Liberalism's Commitment to Its Own Demise." 
one's home and neighborhood and likely entails having to find a new job, make new friends and acquaintances, change many aspects of one's daily routine, and so on. It is a very large upheaval. Having borders redrawn, meanwhile, is less of an upheaval. So, the egregious freedom violations that Joshi has in mind for exclusion are not attendant to territorial exclusion. Second and more crucially, it cannot be the case that territorial exclusion is a bigger infringement on freedom than being prevented from immigrating, because they are the same freedom infringement: both territorial exclusion and immigration restrictions prevent one from moving to the territory of and gaining citizenship in the state of one's choice. Why would this be a bigger violation of freedom in the case of territorial exclusion than in the case of immigration restrictions?

Turning to Joshi's second argument about freedom violations being ripe for abuse, territorial exclusion is likely not as ripe for abuse as deportation. Territorial exclusion requires a state to give up part of itself, which means it cannot be used merely to get rid of dissidents and malcontents without either great cost to the state (in terms of having to work around an inconvenient patchwork border system) or without quickly exhausting the possibility of making use of exclusion (because the state soon runs out of territory that it can exclude). So, if there is something wrong with territorial exclusion, it cannot be that if states have the right to carry it out they will be able to abuse it in ways much more egregious than they can abuse limitations on immigration.

\section{DOES THIS GET US OPEN BORDERS?}

We have addressed the chief objections to the territorial exclusion argument. So far, the argument, if successful, has shown that limitations on immigration also ground a right to exclude territory according to whatever criteria license the immigration limitations. What, then, should we conclude $?^{85}$

Because the territorial exclusion argument is similar in form to the other sorts of exclusion arguments, one might think that my goal has been to argue for open borders. Because the permissibility of immigration restrictions entails the permissibility of territorial exclusion, and because territorial exclusion is suspect for various reasons, borders must be open. Although I am sympathetic to this approach, I think our ultimate conclusion should be more measured and complex. What we should conclude is that theories of who is allowed to cross which borders cannot be constructed absent considerations about which borders ought to be there in the first place. ${ }^{86}$ Thus rather than rejecting out of hand the possibility

85 I thank Tom Parr and an anonymous reviewer for discussion of this point.

86 See Weltman, "The Shifting Boundary Problem." 
of territorial exclusion, we should closely interrogate what is wrong with it and why, and potentially decide that sometimes nothing is wrong with it. Once we have a comprehensive account of what makes it ok to draw borders in the first place, this will allow us to import our conclusions into this present argument in order to figure out whether borders must be open or closed.

My own preferred theory of borders is what Lea Ypi calls a "forward-looking" justification of territorial rights that seeks "a more inclusive perspective" to answer the question of territorial-based "control of people," including exclusion from territory of the sort entailed by closed borders. ${ }^{87}$ This is as opposed to "historical" and "present-oriented" theories that look at how territory has been used so far or that set conditions for what an institution must presently be like in order for it to legitimately control its territory ${ }^{88}$ As Ypi points out, this forward-looking approach is "implicit in many cosmopolitan theories of global justice." ${ }^{89}$ As Wellman puts it, the cosmopolitan position is something like this:

Given that individuals are the only things that ultimately matter morally, and we want states only if and to the extent that they best protect humans, the utterly dismal historical record of state performance on this score seems to suggest an obvious solution: let's break up the existing states and reorganise the world's population into a new political configuration that maximally performs the requisite political tasks. Put bluntly, if states are justified in terms of the functions they perform, shouldn't we organise them in whatever fashion functions best $?^{90}$

The point is indeed put bluntly, but the impetus behind the point is sound. There are reasons not to just take out a pen and start redrawing borders willy-nilly, so the cosmopolitan need not be committed to many immediate radical changes. But the thought is that we should be open to potential changes, and at least we should have a justification for rejecting potential changes, because territorial exclusion represents a potential change that must be evaluated with whatever theory of borders we think is most appropriate.

My aim here is not to defend this particular cosmopolitan approach to territorial exclusion. ${ }^{91}$ What is relevant here is whether a plausible theory of borders will license any territorial exclusion at all, and if it will license exclusion, whether it is plausible to think that this serves as an argument against open borders by

87 Ypi, "Territorial Rights and Exclusion," 251.

88 Ypi, “Territorial Rights and Exclusion," 242.

89 Ypi, “Territorial Rights and Exclusion," 251.

90 Wellman, "Cosmopolitanism, Occupancy and Political Self-Determination," 375-76.

91 For a defense see Weltman, "Cosmopolitan Instrumentalism about Territory." 
suggesting that the state can refuse immigrants for the same reason it can exclude insiders. There are reasons to think that territorial exclusion is at least sometimes justifiable. This is because territorial exclusion is simply unilateral secession, and unilateral secession is not obviously unjustifiable in every possible instance.

For some theorists who argue in favor of closed borders, this simply brings us back to where we were before we started. Specifically, Altman and Wellman already have a theory of secession that is the counterpart to their theory of immigration restrictions. ${ }^{92}$ In their case, the exclusion argument just throws into harsher relief their commitment to a wide variety of permissible secessions. But there are reasons to be skeptical of these theories when it comes to whether they can plausibly deliver immigration restrictions. ${ }^{93}$ When it comes to the territorial exclusion argument specifically, we can better see these sorts of reasons by considering whether and when territorial exclusion is illegitimate. The territorial exclusion argument thus helps us set limits on justifiable immigration restrictions by pointing us toward what would count as unjustified secessions, and it therefore also asks us to determine when secession is and is not justifiable.

Regardless of what we say about Altman and Wellman, the territorial exclusion argument is certainly effective against anyone who endorses closed borders without also endorsing something like and Altman and Wellman's near-unlimited unilateral right to secede. Thus the territorial exclusion argument forces people like Blake to bite the bullet with respect to secession or give up the argument in favor of closed borders. It is likely reasonable to accept that secession is sometimes justified, but it is much less clearly reasonable to accept that any group can justifiably secede for the reasons that ostensibly allow for excluding immigrants according to defenders of closed borders. Altman and Wellman and nationalist theories like Miller's may accept theories of secession like this, but unless we are this accepting of secession, we will have to give up closed borders. ${ }^{94}$ Permissive theories of secession are implausibly strong, and so we should not be this accept-

92 Altman and Wellman, A Liberal Theory of International Justice, ch. 3.

93 Fine, "Freedom of Association Is Not the Answer" and "The Ethics of Immigration"; and Lægaard, “Territorial Rights, Political Association, and Immigration.” Lægaard provides an alternative account of the right to exclude immigrants, but it is based on territorial rights and thus the territorial exclusion argument avoids all of Lægaard's points; see "What Is the Right to Exclude Immigrants?" In territorial exclusion, the state abdicates its territorial rights with respect to the people being excluded, and thus is under no obligation to justify its legitimacy to the excluded people in the way Lægaard argues states are normally obligated.

94 See Miller, "Secession and the Principle of Nationality." 
ing of secession, and thus we should think that states have no pro tanto right to exclude immigrants. ${ }^{95}$

One might worry that this approach proves too much. It can justify territorial exclusion, but it can also justify individual exclusion. If we bite the bullet like Altman and Wellman do, we can license closed borders, but even if we say that unilateral secession is justified only in limited circumstances, this still leaves the door open for some exclusion. This is correct: it is too fast to go straight from an exclusion argument to open borders. Defeating a blanket pro tanto right to exclude does not establish a blanket pro tanto right to immigrate. We should settle for a combination of rejecting closed borders and accepting that we should carefully think through any proposed immigration restrictions to make sure they are compatible with our views about unilateral secession (i.e., territorial exclusion).

Defenders of open borders may not be happy with this. There are two things to say in response. First, the exclusion arguments work by taking the criteria for exclusion of outsiders and showing how these can allow for the exclusion of insiders. It may be that there are no good justifications for excluding outsiders. So perhaps we do get an argument for open borders, not via the exclusion argument but via some other route. The territorial exclusion argument certainly does not rule out open borders. Second, there may be justifications for excluding individuals that are not as clearly objectionable as other sorts of exclusions would be, or as clearly objectionable as existing exclusions are. So for instance there may be a case for excluding people for national security reasons, like agents of a foreign country who unjustly aim to destroy the country they are resident citizens of. If the spies could live perfectly good lives in the country they are loyal to, perhaps there is nothing wrong with excluding them from their present country and revoking their citizenship there. Public health reasons for exclusion, like hypothetically preventing European immigration to the Americas long ago in order to stop the transmission of communicable diseases, could also be justifiable. These sorts of exclusions are ones that even advocates of open borders are typically fine with. ${ }^{96}$ So it may be that, even though the territorial exclusion licenses some border closures, these closures do not actually contest the position typically labeled "open borders."

95 I thank an anonymous reviewer for suggesting that I clarify this point.

96 See, for instance, Carens, "Aliens and Citizens," 251; and Kukathas, "The Case for Open Immigration," 218. Cole is less convinced by national security considerations, both with respect to immigration restrictions and exclusion of existing citizens; see Philosophies of Exclusion, $142-43$. 


\title{
5. CONCLUSION
}

There are two main conclusions that we can take away from the territorial exclusion argument. First, arguments for closed borders are also arguments for territorial exclusion, which means one must either bite the territorial exclusion bullet (like Altman and Wellman) or give up a commitment to closed borders. The bullet is not an attractive one, and so we should give up closed borders. Second, because it is not clear if unilateral secession is always unjustifiable, it is too fast to go directly from the exclusion argument to open borders. Instead we should formulate a comprehensive theory of borders and then read off from this theory what we can say about territorial exclusion, and for that matter other sorts of exclusion. With the possibility of territorial exclusion in mind, we should take care to craft comprehensive theories that would not license widespread territorial exclusion, because this result is too unintuitive to endorse. ${ }^{97}$

\author{
Ashoka University \\ danny.weltman@ashoka.edu.in
}

\section{REFERENCES}

Abizadeh, Arash. "Cooperation, Pervasive Impact, and Coercion: On the Scope (Not Site) of Distributive Justice." Philosophy and Public Affairs 35, no. 4 (Autumn 2007): 318-58.

- "Democratic Theory and Border Coercion: No Right to Unilaterally Control Your Own Borders." Political Theory 36, no. 1 (February 2008): 37-65. —. "The Special-Obligations Challenge to More Open Borders." In Migration in Political Theory, edited by Sarah Fine and Lea Ypi, 105-24. Oxford: Oxford University Press, 2016.

Akhtar, Sahar. "Stripping Citizenship: Does Membership Have Its (Moral) Privileges?" Australasian Journal of Philosophy 95, no. 3 (July 2017): 419-34. Altman, Andrew, and Christopher Heath Wellman. A Liberal Theory of International Justice. New York: Oxford University Press, 2009.

Armstrong, Chris. "National Self-Determination, Global Equality and Moral Arbitrariness." Journal of Political Philosophy 18, no. 3 (November 2010): 313-34. Arneson, Richard J. "Extreme Cosmopolitanisms Defended." Critical Review of International Social and Political Philosophy 19, no. 5 (2016): 555-73.

97 I owe much thanks to two anonymous reviewers for the journal, and to Dan Guillery and Tom Parr for extremely helpful comments. 
Aronovitch, Hilliard. "Why Secession Is Unlike Divorce." Public Affairs Quarterly 14, no. 1 (January 2000): 27-37.

Arrildt, Julie. "State Borders as Defining Lines of Justice: Why the Right to Exclude Cannot Be Justified." Critical Review of International Social and Political Philosophy 21, no. 4 (2018): 500-20.

Beran, Harry. The Consent Theory of Political Obligation. London: Croom Helm, 1987.

Blahuta, Jason P. "How Useful Is the Analogy of Divorce in Theorizing about Secession?" Dialogue 40, no. 2 (Spring 2001): 241-54.

Blake, Michael. "Agency, Coercion, and Global Justice: A Reply to My Critics." Law and Philosophy 35, no. 3 (June 2016): 313-35.

. "Distributive Justice, State Coercion, and Autonomy." Philosophy and Public Affairs 30, no. 3 (Summer 2001): 257-96.

. "Immigration, Jurisdiction, and Exclusion." Philosophy and Public Affairs 41, no. 2 (Spring 2013): 103-30.

. "The Right to Exclude." Critical Review of International Social and Political Philosophy 17, no. 5 (2014): 521-37.

Brezger, Jan, and Andreas Cassee. "Debate: Immigrants and Newcomers by Birth-Do Statist Arguments Imply a Right to Exclude Both?” Journal of Political Philosophy 24, no. 3 (September 2016): 367-78.

Buchanan, Allen. Secession: The Morality of Political Divorce from Fort Sumter to Lithuania and Quebec. Boulder: Westview Press, 1991.

Buckinx, Barbara, and Alexandra Filindra. "The Case against Removal: Jus Noci and Harm in Deportation Practice." Migration Studies 3, no. 3 (November 2015): 393-416.

Buechel, Benedikt. "A Presumptive Right to Exclude: From Imposed Obligations to a Viable Threshold." Global Politics Review 3, no. 1 (2017): 98-108.

Carens, Joseph. "Aliens and Citizens: The Case for Open Borders." Review of Politics 49, no. 2 (Spring 1987): 251-73.

. The Ethics of Immigration. New York: Oxford University Press, 2013.

Carnes, Thomas. "The Right to Exclude Immigrants Does Not Imply the Right to Exclude Newcomers by Birth." Journal of Ethics and Social Philosophy 14, no. 1 (October 2018): 28-43.

Catala, Amandine. "Remedial Theories of Secession and Territorial Justification." Journal of Social Philosophy 44, no. 1 (Spring 2013): 74-94.

Cole, Phillip. Philosophies of Exclusion: Liberal Theory and Immigration. Edinburgh: Edinburgh University Press Ltd., 2000.

Cox, Adam. “Three Mistakes in Open Borders Debates." In Immigration, Emi- 
gration, and Migration: NOMOS LVII, edited by Jack Knight, 51-68. New York: New York University Press, 2017.

Dietrich, Frank. "Secession of the Rich: A Qualified Defence." Politics, Philosophy and Economics 13, no. 1 (February 2014): 62-81.

Ferracioli, Luara. "Citizenship Allocation and Withdrawal: Some Normative Issues." Philosophy Compass 12, no. 12 (December 2017): 1-9.

. "Citizenship for Children: By Soil, by Blood, or by Paternalism?" Philosophical Studies 175, no. 11 (November 2018): 2859-77.

Fine, Sarah. "The Ethics of Immigration: Self-Determination and the Right to Exclude." Philosophy Compass 8, no. 3 (March 2013): 254-68.

_ . "Freedom of Association Is Not the Answer." Ethics 120, no. 2 (January 2010): 338-56.

Frederick, Danny. "Pro-Tanto Versus Absolute Rights." Philosophical Forum 45, no. 4 (2014): 375-94.

Freiman, Christopher. “The Marginal Cases Argument for Open Immigration." Public Affairs Quarterly 29, no. 3 (July 2015): 257-75.

Frick, Johann. "National Partiality, Immigration, and the Problem of Double-Jeopardy." In Oxford Studies in Political Philosophy, vol. 6, edited by David Sobel, Peter Vallentyne, and Steven Wall, 151-82. Oxford: Oxford University Press, 2020.

Gibney, Matthew J. "Should Citizenship Be Conditional? The Ethics of Denationalization." Journal of Politics 75, no. 3 (May 2013): 646-58.

Hidalgo, Javier. "Associative Duties and Immigration." Journal of Moral Philosophy 10, no. 6 (January 2013): 697-722.

- "Self-Determination, Immigration Restrictions, and the Problem of Compatriot Deportation." Journal of International Political Theory 10, no. 3 (October 2014): 261-82.

Hodgson, Louis-Philippe. "A Problem for Global Egalitarianism.” Journal of Moral Philosophy 15, no. 2 (April 2018): 182-212.

Huemer, Michael. "Is There a Right to Immigrate?" Social Theory and Practice 36, no. 3 (July 2010): 429-61.

Joshi, Hrishikesh. "Is Liberalism Committed to Its Own Demise?" Journal of Ethics and Social Philosophy 13, no. 3 (July 2018): 259-67.

Kates, Michael, and Ryan Pevnick. "Immigration, Jurisdiction, and History." Philosophy and Public Affairs 42, no. 2 (Spring 2014): 179-94.

Kukathas, Chandran. "The Case for Open Immigration." In Contemporary Debates in Applied Ethics, and ed., edited by Andrew I. Cohen and Christopher Heath Wellman, 376-88. Malden, MA: John Wiley and Sons, 2014. 
Lægaard, Sune. "Territorial Rights, Political Association, and Immigration." Journal of Moral Philosophy 10, no. 5 (January 2013): 645-70.

."What Is the Right to Exclude Immigrants?" Res Publica 16, no. 3 (October 2010): 245-62.

Lazar, Seth. “Debate: Do Associative Duties Really Not Matter?” Journal of Political Philosophy 17, no. 1 (March 2009): 90-101.

. "A Liberal Defence of (Some) Duties to Compatriots." Journal of Applied Philosophy 27, no. 3 (August 2010): 246-57.

Lefkowitz, David. "Autonomy, Residence, and Return." Critical Review of International Social and Political Philosophy 18, no. 5 (2015): 529-46.

Lenard, Patti Tamara. "Democratic Citizenship and Denationalization." American Political Science Review 112, no. 1 (February 2018): 99-111.

MacKay, Douglas Paul. "Coercion and Distributive Justice: A Defense." Journal of Social Philosophy 47, no. 2 (Summer 2016): 211-30.

Mendoza, José Jorge. "Enforcement Matters: Reframing the Philosophical Debate over Immigration." Journal of Speculative Philosophy 29, no. 1 (2015): 73-90.

Miller, David. National Responsibility and Global Justice. New York: Oxford University Press, 2007.

- On Nationality. Oxford: Clarendon Press, 1995.

"Secession and the Principle of Nationality." Canadian Journal of Philosophy Supplementary Volume 22 (1996): 261-82.

- Strangers in Our Midst. Cambridge, MA: Harvard University Press, 2016. . "Territorial Rights: Concept and Justification." Political Studies 6o, no. 2 (June 2012): 252-68.

. "Why Immigration Controls Are Not Coercive: A Reply to Arash Abizadeh." Political Theory 38 , no. 1 (February 2010): 111-20.

Moore, Margaret. A Political Theory of Territory. New York: Oxford University Press, 2015.

Nagel, Thomas. "The Problem of Global Justice." Philosophy and Public Affairs 33, no. 2 (Spring 2005): 113-47.

Nine, Cara. Global Justice and Territory. Oxford: Oxford University Press, 2012.

."A Lockean Theory of Territory." Political Studies 56, no. 1 (March 2008): $148-65$.

- "The Moral Arbitrariness of State Borders: Against Beitz." Contemporary Political Theory 7 , no. 3 (August 2008): 259-79.

Oberman, Kieran. “Can Brain Drain Justify Immigration Restrictions?" Ethics 123, no. 3 (April 2013): 427-55. 
. "Immigration, Citizenship, and Consent: What Is Wrong with Permanent Alienage?” Journal of Political Philosophy 25, no. 1 (March 2017): 91-107.

_- "Immigration, Global Poverty and the Right to Stay." Political Studies 59, no. 2 (June 2011): 253-68.

Ottonelli, Valeria. “The Right to Stay as a Control Right." In Oxford Studies in Political Philosophy, vol. 6, edited by David Sobel, Peter Vallentyne, and Steven Wall, 87-117. Oxford: Oxford University Press, 2020.

Pevnick, Ryan. Immigration and the Constraints of Justice: Between Open Borders and Sovereignty. Cambridge: Cambridge University Press, 2011.

Philpott, Daniel. “In Defense of Self-Determination.” Ethics 105, no. 2 (January 1995): 352-85.

Rawls, John. A Theory of Justice. Rev. ed. Cambridge, MA: Harvard University Press, 1999.

Sandelind, Clara. "Territorial Rights and Open Borders." Critical Review of International Social and Political Philosophy 18, no. 5 (2015): 487-507.

Scheffler, Samuel. Boundaries and Allegiances: Problems of Justice and Responsibility in Liberal Thought. Oxford: Oxford University Press, 2001.

Seglow, Jonathan. "Associative Duties and Global Justice." Journal of Moral Philosophy 7 , no. 1 (January 2010): 54-73.

Steiner, Hillel. "May Lockean Doughnuts Have Holes? The Geometry of Territorial Jurisdiction: A Response to Nine." Political Studies 56, no. 4 (December 2008): 949-56.

Stilz, Anna. "Decolonization and Self-Determination." Social Philosophy and Policy 32 , no. 1 (Fall 2015): 1-24.

_. "Nations, States, and Territory." Ethics 121, no. 3 (April 2011): 572-601.

. "Occupancy Rights and the Wrong of Removal." Philosophy and Public Affairs 41, no. 4 (Fall 2013): 324-56.

—. "Settlement, Expulsion, and Return." Politics, Philosophy and Economics 16, no. 4 (November 2017): 351-74.

- Territorial Sovereignty: A Philosophical Exploration. Oxford: Oxford University Press, 2019.

Waldron, Jeremy. "Exclusion: Property Analogies in the Immigration Debate." Theoretical Inquiries in Law 18, no. 2 (2017): 469-90.

"A Right to Do Wrong." Ethics 92, no. 1 (October 1981): 21-39.

Walzer, Michael. Spheres of Justice: A Defense of Pluralism and Equality. New York: Basic Books, 1983.

Wellman, Christopher Heath. "Cosmopolitanism, Occupancy and Political Self-Determination." Journal of Applied Philosophy 36, no. 3 (July 2019): 37581. 
_. "Immigration and Freedom of Association." Ethics 119, no. 1 (October 2008): 109-41.

Weltman, Daniel. “Against Innovative Accounts of Self-Determination." Unpublished manuscript.

. "Cosmopolitan Instrumentalism about Territory: A Neglected Alternative." Unpublished manuscript.

. "Illiberal Immigrants and Liberalism's Commitment to Its Own Demise.” Public Affairs Quarterly 34, no. 3 (July 2020): 271-97.

- "Plebiscitary Theories of Secession, Capacity, and Instrumentalism about Secession.” Unpublished manuscript.

- "The Right to Join a State: A Liberal Cosmopolitan Theory of Accession." Unpublished manuscript.

—. "The Shifting Boundary Problem." Unpublished manuscript.

- "Who Is the Self in Self-Determination?" Unpublished manuscript.

Wilcox, Shelley. Review of Immigration and the Constraints of Justice: Between Open Borders and Absolute Sovereignty, by Ryan Pevnick. Ethics 122, no. 3 (April 2012): 617-22.

Young, Iris Marion. Justice and the Politics of Difference. Princeton: Princeton University Press, 1990.

Ypi, Lea. “Territorial Rights and Exclusion.” Philosophy Compass 8, no. 3 (March 2013): 241-53. 